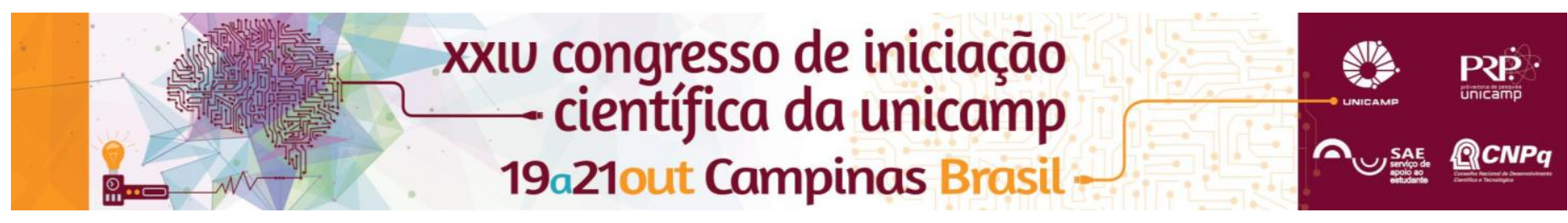

\title{
PERCEPCÕ̃S DOS ALUNOS DO ENSINO MÉDIO PÚBLICO DE LIMEIRA ACERCA DO EMPREENDEDORISMO
}

\author{
Jéssica c. Izeppe *, Edmundo Inácio Júnior
}

\section{Resumo}

Esse trabalho aborda a temática do empreendedorismo. A questão do ensino empreendedor precisa avançar para além das universidades, e chegar ao ensino médio, estimulando-se o espírito empreendedor nos jovens. Foi feito um mapeamento das percepções e experiências que os jovens da rede pública estadual de ensino médio de Limeira têm em relação ao empreendedorismo. Trata-se de um estudo exploratório, descritivo de cunho quantitativo, com uma amostra significativa. Além disso, exploramos a validade e confiabilidade do instrumento Attitudes To Enterprise (ATE) em sua versão em português.

\section{Palavras-chave:}

empreendedorismo, attitudes to enterprise, jovens.

\section{Introdução}

O empreendedorismo tem ganhado importância com o aumento de novas formas de trabalho e do desejo dos indivíduos de se ter uma vivência empreendedora e ter independência profissional. Com uma pesquisa realizada em Limeira - SP foi abordada uma atual discussão sobre empreendedorismo. Realizada com jovens de ensino médio, foi possível examinar dados culturais, sociais e financeiros e através de técnicas de estatísticas descritivas e exploratórias, extrair informações que deram conta de traçar o perfil do estudante de ensino médio das escolas estaduais e suas experiências e percepções sobre as atividades empreendedoras. Além disso, essa pesquisa contribuiu para a análise da validade e confiabilidade do instrumento Attitudes to Enterprise - ATE desenvolvido por Athayde e Hart (2012).

\section{Resultados e Discussão}

Foi realizada a análise fatorial confirmatória que se concentra na exploração dos padrões de relações entre algumas variáveis. Esses padrões são representados por componentes principais ou fatores. Quando variáveis apresentam elevadas cargas sobre um fator, elas se tornam descritoras da dimensão inerente. Dessa maneira, construímos tabelas com cruzamentos simples entre variáveis para análise posterior, como por exemplo, etnia $X$ renda; idade $X$ experiência empreendedora; etnia $X$ realização pessoal. Este trabalho apresenta o método de "avaliação empreendedora" desenvolvida por Athayde, onde se pode medir o grau dos alunos frente a uma série de fatores que inter-relacionam com o empreendedorismo. É um núcleo de comportamentos empreendedores. Foi possível notar que alunos que os pais têm empresa familiar se mostraram melhores nos resultados de avalição empreendedora. Uma hipótese seria a própria convivência no dia a dia que faz com que o indivíduo aprenda de forma empírica sobre o negócio e tenha familiaridade do assunto desde cedo, uma predisposição para ser empreendedor.
Figura 1. Escolas Estaduais de Ensino Médio de Limeira, segundo agrupamentos da amostra

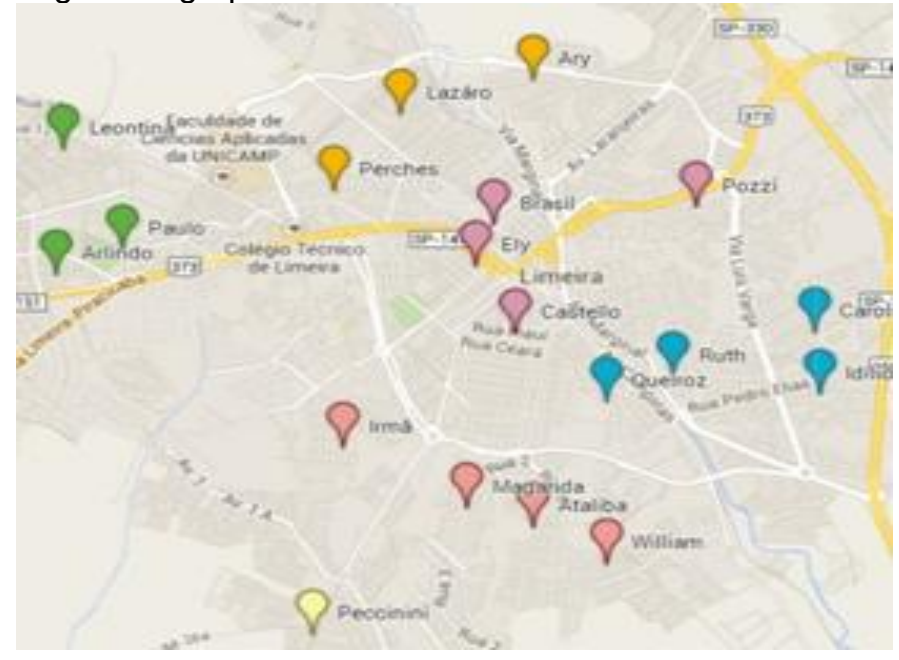

Tabela 2. Características socioeconômicas

\begin{tabular}{|lr|lr|lr|}
\hline \multicolumn{2}{|c|}{ Gênero } & \multicolumn{2}{c|}{ Etnia } & Negócio Próprio \\
\hline Meninos & $46,85 \%$ & Asiáticos & $1,16 \%$ & Sim & $8,06 \%$ \\
Meninas & $48,90 \%$ & Brancos & $50,73 \%$ & Não & $91,94 \%$ \\
Não responderam & $4,25 \%$ & Mulatos & $34,23 \%$ & & \\
& & Negros & $11,60 \%$ & & \\
& & Indigenas & $1,99 \%$ & & \\
& & Não responderam & $0,29 \%$ & \\
\end{tabular}

\section{Conclusões}

Variáveis como a renda familiar e o grau de instrução dos pais afetam o modo de pensar e crescer desses alunos, pois jovens de famílias mais ricas e mais instruídas são mais propensos a terem um maior potencial empreendedor, quando medidos pelo instrumento ATE. Estados deveriam pensar em inserir nas escolas públicas de ensino médio atividades que coloquem o jovem em contato com a cultura empreendedora como forma de encorajá-los a aspirarem uma mobilidade social.

\footnotetext{
${ }^{1}$ ATHAYDE, Rosemary; HART, Mark. Developing a methodology to evaluate enterprise education programmes. International Review of Entrepreneurship, v.10, No3, 2012, pp. 1-24
} 